\title{
Suitable Specimen Types for Newborn Biochemical Screening-A Summary
}

\section{Kate Hall}

International Society for Neonatal Screening, Burgemeester Fabiuspark 55, 3721 CK Bilthoven, The Netherlands; kate@pdsoft.co.uk

Received: 12 May 2017; Accepted: 17 July 2017; Published: 21 July 2017

\begin{abstract}
Newborn biochemical screening has been in place in many countries for over fifty years initially testing dried skin puncture whole blood spotted on collection paper (DBS) or urine for phenylalanine or phenylketones to identify phenylketonuria. Countries wishing to commence newborn screening need to consider which type of specimen will provide a satisfactory specimen and matrix for testing for disorders relevant to their population, is acceptable to parents and can be readily transported to the analytical or laboratory facility without significant degradation. Whilst DBSs have largely become the specimen of choice they may not be applicable to all cultures and infrastructures. The majority of disorders appropriate to be identified in the newborn period can be detected in DBSs taken shortly after birth. Some are also detectable in cord blood or urine, some are not. Most disorders have an ideal and often different time window of age for identification in relation to treatment for optimum outcome. When embarking on newborn screening for the first time or in expanding what is already in place, it is important that the disorders considered are evaluated against the Wilson and Jungner criteria for population screening. A brief overview of specimen types including urine, cord blood and DBSs with some of their advantages and limitations is provided in this review to assist in decision-making.
\end{abstract}

Keywords: newborn screening; specimen type; dried bloodspot screening; urine screening; cord blood screening

\section{Introduction}

Specimens for performing newborn screening biochemical testing have included urine, cord blood and skin puncture blood from the heel variously as liquids or dried onto collection paper. Internationally the widest experience and greatest number of journal articles in print is for the analysis of DBS specimens. Each specimen type has its benefits and some have disadvantages. Which is chosen may depend on a number of factors according to the country or jurisdiction in which neonatal screening will take place. Heel skin puncture blood collection may be considered invasive by some beliefs and the procedure declined. The collection of cord blood or urine may be acceptable in this circumstance. For example, cord blood has been considered to offer advantages of availability in abundance, ethical appropriateness and ensured compliance since it can be collected in all newborns in hospital before discharge [1].

The choice of sample for newborn biochemical screening is thus a complex mix of priorities and practicalities and influenced to a large extent by the main target disorders [2]. Therefore, the prevalence of the proposed target disorders for which the newborn population to be screened is known or expected to benefit by early detection should be taken into account. If this data is unknown, then it may be appropriate to conduct epidemiological surveys to find out. Prevalence may vary widely by geography and ethnic group or ancestry. Metabolite abnormalities in the first weeks of life may be asymptomatic [3]. The optimum time window for sensitive and specific detection of each 
disorder as well as ideal ages by which treatment should be commenced need to be considered as compromises may need to be made or second specimens [4] organised at a later age. For jurisdictions where family planning is desirable and has the greater focus, then disorder identification testing should be conducted as early as possible before the next pregnancy and probably be within the first month after birth. Hypothyroidism is likely to be high on the list of treatable disorders in terms of prevalence for most but not all ethnicities. Its treatment is probably the most affordable in any jurisdiction. Cystic fibrosis has relatively high prevalence but treatment costs are high. Phenylketonuria (PKU) has a very variable prevalence, low in some populations, high in others and has relatively high treatment costs.

Pros and cons of the use of different specimen types of neonatal body fluids for the performance of newborn biochemical screening are considered below to provide pointers to be weighed up by planners. There is no attempt to list all the disorders which could potentially be identified with each specimen type nor are those shown universally recommended as suitable candidates for newborn screening. A list of some available external quality assurance schemes for many newborn screening disorders is provided.

\section{Comparison of Specimen Types for Newborn Biochemical Screening}

Neonatal fluids which have been utilised for biochemical screening include urine, cord blood and skin puncture whole blood from the heel. Each can be analysed in the liquid form or dried onto collection paper and subsequently eluted. Dried samples usually have the advantage of some enhanced analyte stability and ease of mailing. Table 1 compares three different sample types in relation to ease of collection, contamination risk and success in detecting some of the more commonly screened disorders internationally, including congenital hypothyroidism, glucose 6 phosphate dehydrogenase deficiency and sickle cell disease.

Table 1. Factors affecting newborn biochemical screening compared.

\begin{tabular}{|c|c|c|}
\hline Urine & Cord Blood & DBS Collected at a Few Days of Age \\
\hline Non-invasive sample collection. & Generally considered non-invasive. & Semi-invasive sample collection. \\
\hline $\begin{array}{l}\text { A small amount of skill may be needed to } \\
\text { collect. }\end{array}$ & Sample collection requires some skill. & $\begin{array}{l}\text { Requires skill to collect good bloodspots } \\
\text { and to maintain skill by performing a } \\
\text { minimum number per annum }\end{array}$ \\
\hline $\begin{array}{l}\text { Some contamination risk from faeces or } \\
\text { creams on babies' skin. }\end{array}$ & $\begin{array}{l}\text { Contamination risk from maternal } \\
\text { blood exists but is found to be at a low, } \\
\text { acceptable rate in Belgian } \\
\text { haemoglobinopathy studies [5] and } \\
\text { English amino acid studies [6] }\end{array}$ & $\begin{array}{l}\text { Some contamination risk from faeces } \\
\text { and substances on babies' skin or paper } \\
\text { card. }\end{array}$ \\
\hline $\begin{array}{l}\text { Most experience from Quebec [7], Canada } \\
\text { with urine collected onto plastic-backed } \\
\text { absorbent pad then pressed onto filter } \\
\text { paper, dried, as an expansion of pre-MSMS } \\
\text { heel-prick blood screening. }\end{array}$ & Some experience worldwide. & $\begin{array}{l}\text { Vast worldwide experience and many } \\
\text { journal papers on the topic. }\end{array}$ \\
\hline $\begin{array}{l}\text { Can be collected at any age but routinely } \\
\text { collected by parents at } 21 \text { days of age in } \\
\text { Quebec following an instruction sheet [8]. }\end{array}$ & $\begin{array}{l}\text { Reflects babies' biochemical milieu at } \\
\text { birth which is influenced by mother's } \\
\text { metabolism and placenta for non-red } \\
\text { cell analytes. } \\
\text { Cannot be collected by parents. }\end{array}$ & $\begin{array}{l}\text { Can be collected at any age. } \\
\text { Cannot be collected by parents. }\end{array}$ \\
\hline $\begin{array}{l}\text { Can be liquid or dried if collected at home. } \\
\text { Dried is more suitable for mailing. }\end{array}$ & $\begin{array}{l}\text { Can be liquid or dried whole blood. } \\
\text { Serum or whole blood may be } \\
\text { analyzed. }\end{array}$ & $\begin{array}{l}\text { Dried by definition. Liquid skin } \\
\text { puncture blood has been used but is } \\
\text { more suited to cool countries if mailed. }\end{array}$ \\
\hline $\begin{array}{l}\text { Risk of non-collection for individual babies } \\
\text { if suitable birth records to cross-check and } \\
\text { identify do not exist. }\end{array}$ & $\begin{array}{l}\text { Risk of non-collection due to hectic } \\
\text { activity with mother and child after } \\
\text { the baby's birth. }\end{array}$ & $\begin{array}{l}\text { Risk of non-collection for individual } \\
\text { babies if suitable birth records to } \\
\text { cross-check and identify do not exist. }\end{array}$ \\
\hline
\end{tabular}


Table 1. Cont.

\begin{tabular}{lll}
\hline Urine & Cord Blood & DBS Collected at a Few Days of Age \\
\hline $\begin{array}{l}\text { Many inherited disorders, organic } \\
\text { acidaemias and amino acidaemias, can } \\
\text { potentially be detected. Includes urea cycle } \\
\text { disorders and organic acidurias, as well as } \\
\text { transport disorders. }\end{array}$ & $\begin{array}{l}\text { Some organic acidaemias have been } \\
\text { identified due to abnormalities of } \\
\text { acylcarnitine concentration [6,9]. }\end{array}$ & $\begin{array}{l}\text { At least 50 inherited disorders can be } \\
\text { detected when high technology } \\
\text { methods (e.g., tandem mass } \\
\text { spectrometry) are used. }\end{array}$ \\
$\begin{array}{l}\text { Low technology, inexpensive-multiplex thin } \\
\text { layer chromatography may be used. High } \\
\text { technology methodologies may also be } \\
\text { used such as MSMS. }\end{array}$ & $\begin{array}{l}\text { Low and high technology } \\
\text { methodologies possible depending on } \\
\text { the disorder. }\end{array}$ & $\begin{array}{l}\text { Low and high technology } \\
\text { methodogies possible, depending on } \\
\text { the disorder. }\end{array}$ \\
\hline
\end{tabular}

Low concentrations of metabolites for some disorders such as PKU in the first few days of life may preclude early identification. Quebec moved the age of collection from 5 days age to 14 days of age and finally to 21 days to minimise the risk of false negatives and false positives [8]. Late onset urea cycle defects thereby identified.

Lesser sensitivity for detection of the majority of disorders by metabolite accumulation compared to urine or dried skin puncture blood.
Greater sensitivity for detection of the majority of disorders compared to urine or cord blood
SCD and beta thalassaemia major screening successful and satisfactory in Belgian studies using capillary electrophoresis [5]
Sickle cell disease (SCD) cannot be detected

SCD and beta thalassaemia major screening successful and satisfactory by isoelectric focussing, capillary electrophoresis and tandem mass spectrometry for dried blood spots but not by discontinuous cellulose acetate electrophoresis (the latter will work on liquid specimens).

\section{Primary CHT can be detected and} compared well with early DBS screening in Toronto [10].

Congenital hypothyroidism (CHT) cannot readily be detected. Measurement of low excretions of fT4 and fT3 in a timed e.g. 24-h urine test impractical for mass screening and no reference data for neonates has been identified.

Currently used for primary CHT screening in Singapore. More recent study from Abu Dhabi with DELFIA reagents showed cord fT4 to be insensitive, cord TSH to be more sensitive but specificity poorer than DBS [11].

Cystic fibrosis can potentially be detected as IRT is several fold higher

Primary CHT can be detected. Apparent incidence is increasing relentlessly [12]. in concentration than in peripheral blood [13], but sensitivity and specificity have not been determined.

TRECs not identified in urine. SCID cannot TRECs present in cord blood. SCID be detected. can be detected using this specimen.

G6PD deficiency cannot be detected. G6PD deficiency can successfully be detected [14].

17-hydroxyprogesterone noted to be at a significantly higher concentration compared to blood taken at a few days of life. Some authors therefore consider this method not useful for newborn screening, others report that the measurement has potential. Reference concentrations exist.

Classical galactosaemia can be detected by erythrocyte galactose 1 phosphate transferase activity measurement.

Cystic fibrosis can be detected.

\section{.}

SCID can successfully be detected
G6PD deficiency can successfully be
detected.

Congenital adrenal hyperplasia cannot readily be detected. Collection of timed e.g. 17-hydroxyprogesterone excretions impractical for mass screening. Some and older.

Classical galactosaemia can be detected by increased galactose excretion. Requires lactose ingestion [15].
Congenital adrenal hyperplasia can be successfully detected.

Abbreviations: MSMS-tandem mass spectrometry; IRT-immunoreactive trypsin; SCID-severe combined immunodeficiency; TREC-T cell receptor excision circles; fT4-free thyroxine; fT3-free triiodothyronine; DELFIA $^{\mathrm{TM}}$-dissociation enhanced lanthanide fluoro immunoassay; G6PD-glucose 6 phosphatase deficiency 


\section{External Quality Assurance (EQA)}

External quality assurance schemes are important in evaluating newborn screening test results which are issued from the laboratory or testing facility to ensure that they are reliable. Sources of these schemes covering a wide number of analytes are shown in Table 2. Where no suitable schemes exist for the analyte the exchange of normal and abnormal samples between laboratories performing the same test to identify any discrepancies is strongly recommended.

Table 2. External quality assurance schemes.

\begin{tabular}{|c|c|c|c|}
\hline Specimen & EQA Scheme & Free of Charge? & Website Details \\
\hline Urine & ERNDIM & No & http://www.erndim.org/home/qascheme.asp \\
\hline \multirow{5}{*}{ Dried blood spots } & $\begin{array}{l}\text { Centers for Disease Control } \\
\text { Newborn Screening Quality } \\
\text { Assurance Program }\end{array}$ & Yes & http://www.cdc.gov/labstandards/nsqap.html \\
\hline & $\begin{array}{l}\text { UKNEQAS from } \\
\text { Birmingham Quality }\end{array}$ & No & $\begin{array}{c}\text { http://birminghamquality.org.uk/eqa- } \\
\text { programmes/nsa/ }\end{array}$ \\
\hline & $\begin{array}{l}\text { Reference Institute for } \\
\text { Bioanalytics (Germany) }\end{array}$ & No & http://www.dgkl-rfb.de/index_e.shtml \\
\hline & $\begin{array}{l}\text { Asociacion Espanola De } \\
\text { Cribado Neonatal (AECNE) }\end{array}$ & No & http://www.aecne.es \\
\hline & $\begin{array}{l}\text { Preventative Medicine } \\
\text { Foundation, Taiwan. } \\
\text { EQA for Neonatal G6PD }\end{array}$ & No & http://g6pd.qap.tw/ \\
\hline Plasma/Serum/Urine & $\begin{array}{l}\text { College of American } \\
\text { Pathologists (CAP) }\end{array}$ & No & http://www.cap.org \\
\hline
\end{tabular}

Abbreviations: ERNDIM-European Research Network for evaluation and improvement of screening, Diagnosis and treatment of Inherited disorders of Metabolism, UKNEQAS-United Kingdom National External Quality Assessment Service.

\section{Discussion}

Before starting a newborn screening programme or adding to an existing one, a number of factors need to be borne in mind. These include the choice of a suitable and acceptable specimen type for the population, the testing method that is available or affordable, the testing facility and its location. The specimen requires unique identification of the baby and its home location written on or attached to it. Guidance on some of these identification parameters is available in the International Society for Neonatal Screening files in the Members area page 2 [16]. External quality assurance schemes should be sought for all tests.

Occasions may arise in which the testing facility is asked to screen an alternative specimen such as venous or much more rarely arterial whole blood. These specimens may be spotted directly onto the blood collection device/card or spotted as anticoagulated blood. Each variation in specimen type may lead to some differences in reference ranges and potentially to different analytical and referral cut-offs. These cut-offs should be determined for each disorder if alternative specimens are accepted. This particularly applies to the use of serum or anticoagulated plasma. The best practice is to follow a standardized pre-analytical protocol for one sample type [17].

Urine screening for metabolic disorders in parallel with blood screening has been employed by Massachusetts, USA, New South Wales, Australia and Quebec, Canada. Of these, only Quebec has continued the practice, enjoying a high compliance rate of urine collection by parents (around 90\%) in contrast to that experienced in Massachusetts (around 75\%). The disorders which are detected in urine have been considered an effective addition to the screening of newborn blood to detect metabolic disorders [18].

Cord blood is a less utilised fluid for neonatal screening. However, the future for DNA testing by next generation sequencing of uncontaminated cord blood holds some considerable potential as the requirement for metabolite accumulation for disorder identification is eliminated. Its wider adoption 
is limited by long turnaround time, finding variants of unknown significance, incidental/unwanted findings such as carrier detection and the conundrum of mismatching genotype and phenotype. Some of this would be improved by choosing a newborn-specific and targeted gene panel [19].

In conclusion, it is without doubt that the most widely used specimen for newborn screening for biochemical disorders and that for which the most references and reference data exist(s) is for dried heel skin puncture blood taken at a selected number of days after birth. Metabolite accumulation is the main principle of identification.

Acknowledgments: The author would like to thank Irene Williams, Data Management Team, from the Centers for Disease Control, Atlanta for contributing to the table of sources of external quality assurance material and Professor Rodney Pollitt for helpful comments.

The production of the paper, derived from an International Society for Neonatal Screening Council discussion document written by the author, was made at the request of Professor Rodney Howells.

Conflicts of Interest: The author declares no conflict of interest.

\section{References}

1. Anju, S.; Rashmi, M.; Bhakhri, B.K.; Sekri, T. Neonatal thyroid screening: Relationship between cord blood thyroid stimulating hormone levels and thyroid stimulating hormone in heel prick sample on 4th to 7th day-of-life. Indian J. Endocrinol. Metab. 2014, 18, 125-126.

2. Wilson, J.M.G.; Jungner, G. In Principles and Practice of Screening for Disease. WHO Public Health Papers 34. 1968. Available online: http://apps.who.int/iris/bitstream/10665/37650/17/WHO_PHP_34.pdf (accessed on 7 May 2017).

3. Barends, M.; Pitt, J.; Morrissy, S.; Tzanakos, N.; Boneh, A. Biochemical and molecular characteristics of patients with organic acidaemias and urea cycle disorders identified through newborn screening. Mol. Genet. Metab. 2014, 113, 46-52. [CrossRef] [PubMed]

4. Steurweld, U.; Lund, A.M.; Rasmussen, J.; Janzen, N.; Hougaard, D.M. Neonatal screening for primary carnitine deficiency: Lessons learned from the Faroe Islands. Int. J. Neonatal Screen. 2017, 3, 1. [CrossRef]

5. Wolff, F.; Cotton, F.; Gulbis, B. Screening for haemoglobinopathies on cord blood: Laboratory and clinical experience. J. Med. Screen. 2012, 19, 116-122. [CrossRef] [PubMed]

6. Walter, J.H.; Patterson, A.; Till, J.; Besley, G.T.; Fleming, G.; Henderson, M.J. Bloodspot acylcarnitine and aminoacid analysis in cord blood samples: Efficacy and reference data from a large cohort study. J. Inherit. Metab. Dis. 2009, 32, 95-101. [CrossRef] [PubMed]

7. Auray-Blais, C.; Giguere, R. Newborn urine screening programme in the province of Quebec: An update of 30 years' experience. J. Inherit. Metab. Dis. 2003, 26, 393-402. [CrossRef] [PubMed]

8. Auray-Blais, C.; Cyr, D.; Drouin, R. Quebec neonatal mass urine screening: From micro to macromolecules. J. Inherit. Metab. Dis. 2007, 30. [CrossRef] [PubMed]

9. Walfish, P.G.; Ginsberg, J.; Rosenberg, R.A. Results of a regional cord blood screening programme for detecting neonatal hypothyroidism. Arch. Dis. Child. 1979, 54, 171-177. [CrossRef] [PubMed]

10. Ensenauer, R.; Fingerhut, R.; Maier, E.M.; Polanetz, R.; Olgemöller, B.; Röschinger, W.; Muntau, A.C. Newborn screening for isovaleric acidemia using tandem mass spectrometry: data from 1.6 million newborns. Clin. Chem. 2011, 57, 623-626, Supplemental online material. [CrossRef] [PubMed]

11. Hardy, J.D.; Zayed, R.; Doss, I. Cord blood thyroxine and thyroid stimulating hormone screening for congenital hypothyroidism: How useful are they? J. Pediatr. Endocrinol. Metab. 2008, 21. [CrossRef]

12. Pollitt, R.J. Evidence or enthusiasm? Why yields from UK newborn screening programmes for congenital hypothyroidism are increasing. Arch. Dis. Child. 2016, 101. [CrossRef] [PubMed]

13. Borgstrom, A.; Sveger, T.; Lindberg, T.; Kullander, S.; Svanberg, L. Immunoreactive trypsin, chymotrypsin, and pancreatic secretory trypsin inhibitor in cord blood from infants with cystic fibrosis. Acta Paediatr. 1981, 70, 619-621. [CrossRef]

14. Muzzafar, M.A. Neonatal screening of glucose-6-phosphate dehydrogenase deficiency in Yanbu, Saudi Arabia. J. Med. Screen. 2005, 12. [CrossRef] [PubMed]

15. Monk, A.M.; Mitchell, A.J.H.; Milligan, D.W.A.; Holton, J.B. Diagnosis of classical galactosaemia. Arch. Dis. Child. 1977, 52, 943-946. [CrossRef] [PubMed] 
16. General Guidelines and Related Documents. Design of Blood Collection Devices (Cards)-Items for Consideration. January 2016. Available online: https://www.isns-neoscreening.org/ (accessed on 27 April 2017).

17. Brauer, R.; Leichtle, A.B.; Fiedler, G.M.; Thiery, J.; Ceglarek, U. Preanalytical standardization of amino acid and acylcarnitine metabolite profiling in human blood using tandem mass spectrometry. Metabolomics 2011, 7, 344-352. [CrossRef]

18. Levy, H.L.; Coulombe, J.T.; Shih, V.E. Newborn Urine Screening. In Neonatal Screening for Inborn Errors of Metabolism; Bickel, H., Guthrie, R., Hammerson, G., Eds.; Springer: Berlin, Germany; New York, NY, USA, 1980; pp. 89-103.

19. Bhattacharjee, A.; Sokolsky, T.; Wyman, S.; Wyman, S.K.; Reese, M.G.; Puffenberger, E.; Strauss, K.; Morton, H.; Parad, R.B.; Naylor, E.W. Development of DNA confirmatory and high-risk diagnostic testing for newborns using targeted next-generation DNA sequencing. Genet. Med. 2015, 17, 337-347. [CrossRef] [PubMed]

(C) 2017 by the author. Licensee MDPI, Basel, Switzerland. This article is an open access article distributed under the terms and conditions of the Creative Commons Attribution (CC BY) license (http://creativecommons.org/licenses/by/4.0/). 